\title{
Adaptability and Evaluation of Improved Orange Fleshed Sweet Potato (Ipomoea batatas L.) Varieties in the Mid Altitude of Guji Zone, Southern Ethiopia
}

\author{
Solomon Teshome*, Arega Amide, Tekile Bobo \\ Oromia Agricultural Research Institute, Bore Agricultural Research Center, Bore, Ethiopia \\ Email address: \\ solomtesh41@gmail.com (S. Teshome) \\ ${ }^{*}$ Corresponding author \\ To cite this article: \\ Solomon Teshome, Arega Amide, Tekile Bobo. Adaptability and Evaluation of Improved Orange Fleshed Sweet Potato (Ipomoea batatas L.) \\ Varieties in the Mid Altitude of Guji Zone, Southern Ethiopia. Advances in Bioscience and Bioengineering. Vol. 8, No. 2, 2020 , pp. 31-37. \\ doi: 10.11648/j.abb.20200802.14
}

Received: June 29, 2020; Accepted: July 25, 2020; Published: August 10, 2020

\begin{abstract}
Low yields and yield instability due to the use of old land races were limiting sweet potato production by resource-poor farmers in the zone. The Experiment was conducted at Bore Agricultural Research Center during 2018 and 2019 summer cropping season at Adola sub station and on-farm with the objective of identifying the cultivars, which could have wide or specific adaptations, and to select and recommend adaptable, frost and disease tolerant and high yielding orange type sweet potato cultivars for midlands of Guji Zone. To this effect four (Kaboli, Naspot 12, Naspot 13, Kaboli and local) improved orange varieties of sweet potato, Ipomoea batatas L., based on their yield and disease resistance performance were tested in RCBD with three replications with the spacing of $100 \mathrm{~cm} * 30 \mathrm{~cm}$ between rows and plants, respectively. A widely cultivated variety (Local) was included as check. The combined analysis of variance across locations showed significant variation among genotypes and locations interaction for the number of roots, root weight, marketable yield, unmarketable yield and total storage root yield ( $\mathrm{t} / \mathrm{ha})$. Based on this, the maximum mean value of root number per plot $(21.33,36.66$ and 21.33$)$ was recorded from Naspot-13, Naspot-12 and Naspot-13 variety at Dufa, Boke and Gobicha sites, respectively. However the minimum $(16.00,19.33$ and 16.00) mean value of root number was recorded from Local Variety across locations. The maximum fresh root weight $(670.33 \mathrm{~g}$ and $444 \mathrm{~g})$ was recorded for Kabode and NASPOT-13 Variety over locations. On the other hand, the lowest fresh root weight $(447.33,437.33 \mathrm{~g}$ and $296.33 \mathrm{~g})$ was recorded by Kaboli variety at all locations. The highest mean value of total root yield $\left(65.09 \mathrm{t} \mathrm{ha}^{-1}\right.$ and $\left.59.88 \mathrm{t} \mathrm{ha}^{-1}\right)$ was recorded by Naspot-13 at Dufa and Gobicha locations in 2018 and 2019 cropping seasons. While Naspot-12 gave maximum $\left(55.16 \mathrm{t} \mathrm{ha}^{-1}\right)$ total root yield at Boke location. However Kaboli gave the least $\left(43.09,27.19\right.$ and $\left.37.69 \mathrm{t} \mathrm{ha}^{-1}\right)$ total root yield over locations and years. Therefore Naspot 13 and Naspot12 sweet potato varieties were more adaptable, disease tolerant and high yielder and should be promoted to farmers of the study areas for optimum production.
\end{abstract}

Keywords: Improved Variety, Ipomoea Batatas, Naspot-12, Naspot-13, Sweet Potato

\section{Background}

Root and tuber crops, including cassava, sweet potato, potato and yam are the most important food crops for direct human consumption in Africa. These four crops are grown in varied agro-ecologies and production systems contributing to more than 240 million tons annually, covering around 23 million hectares. There are many compelling reasons for encouraging these humble root and tuber crops for sustainable food production. Among those sweet potatoes are short cycle crops and thus well suited to the double cropping seasons particularly the rain-fed system. Likewise, this crop is one of the root and tuber crops grown in Ethiopia, and it is the third important root crop next to Enset and Potato [6].

Sweet potato is a member of convolvulaceae family, genus Ipomia and species batatus [13]. It is accepted that the cultivated sweet potato has originated in Central America or tropical South America. Globally it is grown in an area of 
about 9.26 million hectares with a production of 126.18 million tons; average productivity being 13.6ton ha-1 [17]. Sweet potato is an important low-input crop for many places in sub-Saharan Africa. This crop is also capable in efficiently converting natural resources into a more usable product, caloric energy in the growing season, which is the highest of all major arable crops. As pressure on agricultural land increases, improved productivity of these crops will be needed. Women play a critical role in the production of these crops; therefore, it is critical consider improvement of these crops as a means to relieve gender in-equality within agricultural systems. Strategic investment would ensure effective variety development and adoption to accelerate impact of technology.

The use of bio-fortified orange sweet potato rich in betacarotene, when introduced along with nutrition education at the community level, is a proven cost-effective strategy for providing vitamin A at high levels of bioavailability to vulnerable populations, in particular young children and pregnant and lactating women. On all these accounts, it enhances the resilience of smallholder farming that is frequently affected by low yields or crop failure of other staple crops due to weather or disease. In parts of Ethiopia sweet potato is a relatively new crop and much less prevalent. However absence of improved sweet potato varieties in the zone also has been a critical problem to its production and productivity [8].

There are a number of biophysical and socio-economic constraints that hinder the productivity of sweet potato under farmers' circumstances. Among others, lack of high yielding and acceptable quality, and pest resistant /tolerant varieties and agronomic practices has been the limiting factors. To mitigate the limiting factors and constraints of sweet potato production and productivity, improvement activities with the objectives to develop high yielding with acceptable quality and/or pest resistant/tolerant varieties for different agroecological zones has been one of the themes. Therefore, efforts have been made to develop improved technologies such as varieties that are high yielder, resistant to disease and pests, and high above ground biomass for livestock feed.

\section{Literature Review}

\subsection{Origin and Distribution}

Sweet potato originated from tropical Central America. Botanically, the underground part is classified as a storage root, rather than a tuber. It can be cultivated in many different climatic conditions; and as a result large areas of sweet potato are cultivated in Asia, Africa, Europe, America and Oceania [12]. Ethiopia ranks fifteenth in the world in terms of sweet potato production [2]. It has been cultivated as crop in Ethiopia for several years and over $95 \%$ of the crop produced in the country is grown in south, south western and eastern parts of the country, where it has remained for centuries as an important staple for the community [4]. In Ethiopia sweet potato ranks the first in total production
$(42.84 \%)$ and the second in area coverage $(25.43 \%)$ next to Irish potato from root and tuber crops cultivated [1].

\subsection{Climatic Requirements and Importance}

Sweet potatoes are of tropical origin; they adapt well to warm climates and grow best during summer. Sweet potatoes are cold sensitive and should not be planted until all danger of frost is past. The optimum temperature to achieve the best growth of sweet potatoes is between 21 and $29^{\circ} \mathrm{C}$, although they can tolerate temperatures as low as $18^{\circ} \mathrm{C}$ and as high as $35^{\circ} \mathrm{C}$. A well-drained sandy loam is preferred and heavy clay soils should be avoided as they can retard root development, resulting in growth cracks and poor root shape. Soil $\mathrm{pH}$ should be adjusted to about 6.0 by applying lime or dolomite.

Orange-fleshed sweet potato (OFSP) contains high levels of beta-carotene, which is converted by the body into vitamin A. Just $125 \mathrm{~g}$ of boiled OFSP can provide the recommended daily allowance of vitamin A for children and women who are not breastfeeding. In addition, OFSP contributes significant amounts of vitamins C, E and several B vitamins, as well as dietary fiber, iron and magnesium. Purple-fleshed varieties, on the other hand, are rich sources of antioxidants. Sweet potato leaves are also rich in vitamins, beta-carotene, and functional compounds including protein, amino acids and complex carbohydrates. Cultivated primarily for edible storage roots; vines are used as vegetables in some parts of the world. Both starchy roots and vines can be used as animal feed or feed supplement. Various products such as candy, pastas, flour, drinks are produced in local industries. Sweet potato is a dual-purpose crop, as the roots are edible, and the tops may be consumed as a green vegetable. Although the leaves and shoots are also edible, the starchy tuberous roots are by far the most important product. In some tropical areas, they are a staple food-crop. Apart from the utilization of the roots, stems and leaves are readily eaten by cattle, goats, pigs, poultry and even fish when green or as hay or silage. Humans consume vines as a green vegetable or salad green [10].

Seasonal food shortage is amongst the principal problems of farmers in mid-altitude areas of Southern Ethiopia. Sweet potato is one of the most important root and tuber crop for food and feed value. It is one of the twelve principal plant species utilized as a human feed throughout the world. In some of the worlds poorest nations, taro and sweet potato are important part of food security packages [18]. Its root is used as food and feed. As food the root is usually consumed in boiled form. It is one of the cheapest sources of vitamin A.

Generally Sweet potatoes productivity is law under farmer condition due to many factors one of which will be lack of improved varieties. Endale et al [5] indicated that yield in farmers field is low mainly because of unavailability of improved genotypes and poor agronomic practices. One of the main constraints among others in increasing yield $\mathrm{ha}^{-1}$ is lack of varieties of the crop which is adapted to specific condition of the area.

Most sweet potato growers are resource poor, therefore 
consume imbalanced diets. Most sweet potatoes varieties currently grown by farmers are poorly adapted, have low root yields, less nutritive and white fleshed which have no beta carotene, a precursor to vitamin A [16]. But among the cheapest and richest sources of vitamin A, orange type varieties, rich in beta carotene are well accepted by young children [8]. The intensity of orange colored flesh sweet potatoes root indicates the level of beta carotene [7]. Therefore, these OFSP varieties could be useful to combat the widespread of vitamin A deficiency that results in blindness and death of 250,000-500,000 African children yearly [16]. Therefore developing and making available adaptable, high yielding and pest and disease tolerant varieties of Sweet potato is a priority concern in its productivity increase strategy. The main objective of the present study was to identify the cultivars, which could have wide or specific adaptations, and to select and recommend adaptable, frost and disease tolerant and high yielding sweet potato cultivars for midlands of Guji Zone.

\section{Materials and Methods}

\subsection{Description of the Study Area}

The Experiment was conducted at Bore Agricultural Research Center during 2018 and 2019 summer cropping season at Adola sub-station, Gobicha, and Boke on-farm site with the objective of identifying the cultivars, which could have wide or specific adaptations, and to select and recommend adaptable, frost and disease tolerant and high yielding orange type sweet potato cultivars for midlands of Guji Zone. The area is located in Guji zone southern Ethiopia estimated $470 \mathrm{~km}$ far from Addis Ababa. Astronomically the district is located between $05^{0} 53680$ and $038^{\circ} 59007$ northing and easting latitude respectively.

\subsection{Treatments and Experimental Design}

Five (Kaboli, Naspot 12, Naspot 13, Kaboli and local) varieties of orange fleshed sweet potato, Ipomoea batatas L., varieties based on their yield and disease resistance performance was tested with the spacing of $100 \mathrm{~cm} * 30 \mathrm{~cm}$ between rows and plants, respectively. Area occupied by a single plot is $4 \mathrm{~m} \times 2.4 \mathrm{~m}$, with a spacing of $1.5 \mathrm{mx} 1 \mathrm{~m}$ between block and plot respectively. Thirty two cuttings of each variety were planted on the plot. A randomized complete block design with three replicates was used. The Net harvestable plot was $2 \mathrm{~m} \times 2.4 \mathrm{~m} \times\left(4.8 \mathrm{~m}^{2}\right)$. Total storage root yield data was taken during the study and the central two rows were harvested from each plot leaving border rows to avoid border effects.

\subsection{Experimental Procedures and Field Management}

The experimental land was ploughed, disked and harrowed and ridges were prepared manually with traditional hoes. At crop stand date of planting, plant height at maturity number of main stem branches and no of population at harvesting was recorded. At harvest average root diameter, average root length, number of root per plot, total root weight per hectare, marketable root yield per hectare and unmarketable root yield per hectare also recorded. $100 \mathrm{~kg}$ of UREA and NPS fertilizers was used. Other agronomic and crop protection practices will be adopted uniformly as per recommendation for production. Harvesting was done five months after planting (5MAP) at all sites and data on final stand count, representing final surviving plants in a net plot was recorded. Using a weighing scale, fresh root yield $(\mathrm{kg})$ per plot was determined with marketable and unmarketable roots considered for analysis. Analysis of variance for the collected parameters was performed as per the methods described by Gomez and Gomez (1984) using SAS computer software (SAS, 2003) for randomized complete block design and treatment mean comparison is done by Fishers list significance difference (LSD) at 5\%. Correlation analysis among growth parameters was also done, using Pearson correlation analysis of SAS version 9.3 statistical software [14].

Table 1. Description of the five orange fleshed sweet potato varieties used as experimental.

\begin{tabular}{llll}
\hline $\begin{array}{l}\text { Name of the } \\
\text { variety }\end{array}$ & $\begin{array}{l}\text { Year of } \\
\text { release }\end{array}$ & Source/breeder & Type \\
\hline Naspot 13 & & AwARC & Orange fleshed \\
Local & & Local community & Orange fleshed \\
Kaboli & AwARC & Orange fleshed \\
Kabode & AwARC & Orange fleshed \\
Naspot 12 & AwARC & Orange fleshed \\
\hline
\end{tabular}

Source: Awasa Agricultural Research Center

\section{Result and Discussions}

The present experiment was conducted to find out the cultivars, which could have wide or specific adaptations, and to select and recommend adaptable, frost and disease tolerant and high yielding orange fleshed type sweet potato cultivars. Therefore, the difference of cultivars on growth and yield of sweet potato have been presented and discussed in different tables and figures in this chapter. The results of the experiment and possible interpretations have been made under the following headings.

\subsection{Survival Rate, Days to Maturity, Number of Roots Per Plot and Average Root Weight}

\subsubsection{Survival Rate}

All cultivars has a very highly significantly $(\mathrm{P}<0.001)$ increased most of the growth and yield related parameters considered in this study at Dufa, Gobicha and Boke. So plant survival rate was highly significantly $(\mathrm{P}<0.05)$ different between varieties. The analysis of variance showed that sweet potato varieties Local $(90.62 \%, 90.20 \%$ and $90.42 \%)$, Kabode (78.12\% and $78.12 \%)$ and NASPOT-13 (84.37\%) were recorded the highest survival rate at Dufa, Boke and Gobicha locations, respectively. The lowest survival rate $(71.87 \%)$ and $(67.71 \%)$ were recorded by Napot-12 and Kaboli variety at Dufa and Gobicha locations, respectively (Table 2, Table 4 and Table 6). 


\subsubsection{Days to Maturity}

Analysis of data for both varieties revealed non-significant $(\mathrm{P}>0.05)$ result on maturity date at Dufa and Gobicha site (Table 2 and Table 6). However days to maturity at Boke site showed significant $(\mathrm{P}<0.05)$ difference among each cultivars. The maximum day to maturity (166.66) was recorded for NASPOT-13 and the minimum days to maturity (143.33) was recorded for local variety at Boke location.

\subsubsection{Number of Roots Per Plot}

According to the results of ANOVA, highly significant $(\mathrm{P}<0.05)$ differences were occurred in number of roots among the sweet potato varieties at Dufa, Boke and Gobicha (Table 2, Table 6 and Table 6). The highest mean value of root number per plot $(21.33,36.66$ and 21.33) was recorded from Naspot-13, Naspot-12 and Naspot-13 variety at Dufa, Boke and Gobicha sites, respectively. However the lowest $(16.00,19.33$ and 16.00) mean value of root number was recorded from Local Variety in this experiment compared to the remaining four varieties at Dufa, Boke and Gobicha sites, respectively (Table 2, Table 4 and Table 6). This root number difference may be come from genetic capability of the sweet potato varieties [9].

\subsubsection{Average Root Weight}

Average Fresh root weight was significantly $(\mathrm{P}<0.05)$ different among the sweet potato varieties evaluated for their adaptability at Dufa for two years, Boke and Gobicha (Table 2, Table 4 and Table 6). The maximum fresh root weight (670.33g and 444g) was recorded for Kabode and NASPOT13 Variety at all locations. On the other hand, the lowest fresh root weight $(447.33,437.33 \mathrm{~g}$ and $296.33 \mathrm{~g}$ ) was recorded by Kaboli variety at all locations, which was probably the poorest in fresh weight among the newly introduced five improved varieties tested in the agro ecological zone in the southern Oromia.

Table 2. Pooled Means of phenology and yield related variables of sweet potato variety adaptation trial at Dufa during 2018 and 2019 cropping season.

\begin{tabular}{lllll}
\hline \multirow{2}{*}{ Treatments } & \multicolumn{4}{l}{ Phenology and yield related } \\
\cline { 2 - 5 } & SR (\%) & DM & NRPP & ARW(g) \\
\hline NASPOT 13 & $72.91^{\mathrm{b}}$ & 134.00 & $21.33^{\mathrm{a}}$ & $581.66^{\mathrm{b}}$ \\
LOCAL & $90.62^{\mathrm{a}}$ & 152.33 & $16.00^{\mathrm{b}}$ & $525.33^{\mathrm{bc}}$ \\
KABOLI & $76.04^{\mathrm{b}}$ & 142.33 & $18.33^{\mathrm{ab}}$ & $437.33^{\mathrm{d}}$ \\
KABODE & $78.12^{\mathrm{b}}$ & 136.66 & $18.00^{\mathrm{ab}}$ & $670.33^{\mathrm{a}}$ \\
NASPOT 12 & $71.87^{\mathrm{b}}$ & 135.00 & $17.66^{\mathrm{b}}$ & $491.33^{\text {cd }}$ \\
Mean & 77.91 & 140.06 & 18.26 & 541.26 \\
LSD (5\%) & 12.36 & $\mathrm{~ns}$ & 3.63 & 60.82 \\
CV (\%) & 8.72 & 7.2 & 24.19 & 6.17 \\
\hline
\end{tabular}

Means in columns and rows followed by the same letter(s) are not significantly different at $5 \%$ level of significance. Where $\mathrm{SR}=$ survival rate, $\mathrm{DM}=$ date to maturity, $\mathrm{NRPP}=$ average root number per plot, $\mathrm{ARW}=$ average root weight $(\mathrm{g})$.

\subsection{Marketable Fresh Yield, Unmarketable Fresh Yield and Total Root Yield}

\subsubsection{Marketable Fresh Yield}

The analysis of variance (ANOVA) indicated high significant differences in fresh root yield, unmarketable fresh yield and total root yield ( $\mathrm{t} / \mathrm{ha}$ ) among varieties at $\mathrm{P}<0.05$ within and among locations and seasons (Table 3, Table 5 and Table 6). From the analysis of the result, there were high significance difference between the varieties at $\mathrm{P}<0.05$. The maximum root yield ( 63.28 $\mathrm{t} \mathrm{ha}^{-1}$ and $58.08 \mathrm{t} \mathrm{ha}^{-1}$ ) was recorded by variety Naspot-13 at Dufa and Gobicha locations in 2018 and 2019 cropping seasons. But our Anova analysis showed that Naspot-12 was recorded maximum $\left(50.76 \mathrm{t} \mathrm{ha}^{-1}\right)$ fresh root yield at Boke location during 2018 cropping year. However the lowest tuber yield (39.64, 22.78 and $34.44 \mathrm{t} \mathrm{ha}^{-1}$ ) was recorded by varieties Kaboli at all locations for both seasons (Tables 3, 5 and 6). The variability in yield by different genotypes indicated their differing responses to diverse environments and seasons (Mulema et al., 2008). The difference in performance among the cultivars in a given environment is in part due to genetic variability. Tesfaye et al. (2011) also reported that significant variation between sweet potato genotypes in yield and other desirable traits in their adaptation trial in different agro ecologies of Ethiopia. Generally this signifies the varieties to wider or specific adaptation to maximum or low yielding as compared to other varieties.

Table 3. Pooled Means of yield variables of sweet potato variety adaptation trial at Dufa during 2018 and 2019 cropping season.

\begin{tabular}{llll}
\hline \multirow{2}{*}{ Treatments } & \multicolumn{3}{l}{ Yield variables } \\
\cline { 2 - 4 } & MRK(t/ha) & UMRK(t/ha) & TRY(t/ha) \\
\hline NASPOT 13 & $63.28^{\mathrm{a}}$ & $1.80^{\mathrm{b}}$ & $65.08^{\mathrm{a}}$ \\
LOCAL & $55.22^{\mathrm{bc}}$ & $1.96^{\mathrm{b}}$ & $57.19^{\mathrm{bc}}$ \\
KABOLI & $39.64^{\mathrm{d}}$ & $3.45^{\mathrm{a}}$ & $43.09^{\mathrm{d}}$ \\
KABODE & $50.60^{\mathrm{c}}$ & $1.07^{\mathrm{c}}$ & $51.68^{\mathrm{c}}$ \\
NASPOT 12 & $60.21^{\mathrm{ab}}$ & $2.47^{\mathrm{b}}$ & $62.69^{\mathrm{ab}}$ \\
Mean & 53.79 & 2.15 & 55.95 \\
LSD (5\%) & 6.06 & 0.72 & 5.62 \\
CV (\%) & 6.19 & 18.37 & 5.52 \\
\hline
\end{tabular}

Means in columns and rows followed by the same letter(s) are not significantly different at $5 \%$ level of significance. Where, MRK=marketable fresh weight per hectare $(\mathrm{t})$; UMRK=unmarketable fresh weight per hectare $(\mathrm{t}) ; \mathrm{TRY}=$ total root yield $(\mathrm{t})$.

Table 4. Means of sweet potato variety adaptation trial at Boke during 2018 cropping season.

\begin{tabular}{lllll}
\hline \multirow{2}{*}{ Treatments } & \multicolumn{4}{l}{ Phenology and yield related Variables } \\
\cline { 2 - 5 } & SR (\%) & DM & NRPP & ARW(g) \\
\hline NASPOT 13 & $84.37^{\mathrm{a}}$ & $166.66^{\mathrm{a}}$ & $26.66^{\mathrm{b}}$ & $444^{\mathrm{a}}$ \\
LOCAL & $90.20^{\mathrm{a}}$ & $143.33^{\mathrm{c}}$ & $19.33^{\mathrm{c}}$ & $343^{\mathrm{b}}$ \\
KABOLI & $67.71^{\mathrm{c}}$ & $161^{\mathrm{b}}$ & $14.33^{\mathrm{d}}$ & $296.33^{\mathrm{b}}$ \\
KABODE & $78.12 \mathrm{~b}^{\mathrm{c}}$ & $145^{\mathrm{c}}$ & $22 \mathrm{~b}^{\mathrm{c}}$ & $298^{\mathrm{b}^{\mathrm{b}}}$ \\
NASPOT 12 & $82.29^{\mathrm{ab}}$ & $165.66^{\mathrm{ab}}$ & $33.66^{\mathrm{a}}$ & $470.33^{\mathrm{a}}$ \\
Mean & 80.62 & 156.33 & 23.20 & 370.33 \\
LSD (5\%) & 10.68 & 5.39 & 4.90 & 61.39 \\
CV (\%) & 7.28 & 1.89 & 11.61 & 9.11 \\
\hline
\end{tabular}

Means in columns and rows followed by the same letter(s) are not significantly different at $5 \%$ level of significance. Where $\mathrm{SR}=$ survival rate, $\mathrm{DM}=$ date to maturity, $\mathrm{NRPP}=$ average root number per plot, $\mathrm{ARW}=$ average root weight $(\mathrm{g})$

\subsubsection{Unmarketable Fresh Yield}

Analysis of data for cultivars has revealed highly 
significant $(\mathrm{P}<0.05)$ different on unmarketable root yield at Dufa and Gobicha locations. But non-significant (P. 0.05) different result at Boke location. The highest unmarketable fresh yield (3.45 and $3.25 \mathrm{t} \mathrm{ha}^{-1}$ ) was recorded for Kaboli variety, while the lowest mean value (1.00 and $\left.1.07 \mathrm{t} \mathrm{ha}^{-1}\right)$ was recorded by Kabode variety. According to the report of Egbe et al. [3], during the growth of sweet potato substantial morphological changes occur which could be different among varieties and these influences the accumulation or distribution of the total dry matter among the major plant organs and directly contributing to the difference in fresh weight.

\subsubsection{Total Root Yield}

The analysis of variance showed that sweet potato varieties has highly significant $(\mathrm{P}<0.05)$ different on total fresh root yield at all locations for both years. The maximum total root yield (65.09 $\mathrm{t} \mathrm{ha}^{-1}$ and $59.88 \mathrm{t} \mathrm{ha}^{-1}$ ) was recorded by variety Naspot-13 at Dufa and Gobicha locations in 2018 and 2019 cropping seasons. While variety Naspot-12 gave maximum $\left(55.16 \mathrm{t} \mathrm{ha}^{-1}\right)$ total root yield at Boke site. However variety kaboli gave the least $\left(43.09,27.19\right.$ and $\left.37.69 \mathrm{t} \mathrm{ha}^{-1}\right)$ total root yield at all sites. The variation observed in root yield is expected since the varieties had different origins and adaptability preference.

Table 5. Means of sweet potato variety adaptation trial at Boke during 2018 cropping season.

\begin{tabular}{llll}
\hline \multirow{2}{*}{ Treatments } & \multicolumn{2}{l}{ Yield variables } & \\
\cline { 2 - 4 } & MRK(t/ha) & UMRK(kt/ha) & TRY(t/ha) \\
\hline NASPOT 13 & $48.86^{\mathrm{b}}$ & 5.049 & $53.90^{\mathrm{a}}$ \\
LOCAL & $43.209^{\mathrm{c}}$ & 1.736 & $44.94^{\mathrm{b}}$ \\
KABOLI & $22.78^{\mathrm{e}}$ & 4.410 & $27.19^{\mathrm{d}}$ \\
KABODE & $38.19^{\mathrm{d}}$ & 2.00 & $40.19^{\mathrm{c}}$ \\
NASPOT 12 & $50.76^{\mathrm{a}}$ & 4.403 & $55.16^{\mathrm{a}}$ \\
Mean & 40.7 .6 & 3.519 & 44.28 \\
LSD (5\%) & 16.53 & $\mathrm{~ns}$ & 43.30 \\
CV (\%) & 2.22 & 63.14 & 5.37 \\
\hline
\end{tabular}

Means in columns and rows followed by the same letter(s) are not significantly different at $5 \%$ level of significance. Where, MRK=marketable fresh weight per hectare $(\mathrm{t})$; UMRK=unmarketable fresh weight per hectare $(\mathrm{t}) ; \mathrm{TRY}=$ total root yield $(\mathrm{t} / \mathrm{ha})$

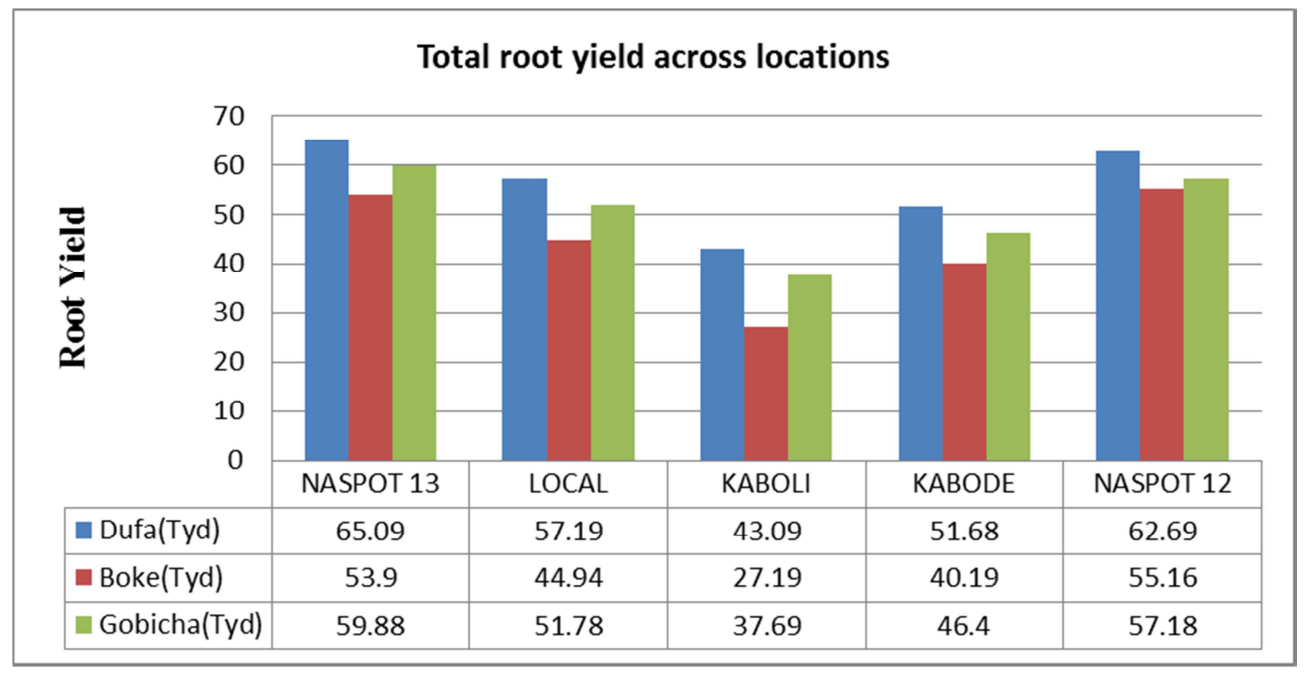

Figure 1. Total fresh root yield of sweet potato at Dufa, Boke and Gobicha locations.

Table 6. Means of sweet potato variety adaptation trial at Gobicha during 2019 cropping season.

\begin{tabular}{|c|c|c|c|c|c|c|c|}
\hline \multirow{2}{*}{ Treatments } & \multicolumn{7}{|c|}{ Phenology, Growth and yield variables } \\
\hline & SR (\%) & DM & NRPP & $\operatorname{ARW}(\mathbf{g})$ & $\operatorname{MRK}(\mathbf{t} / \mathbf{h a})$ & $\operatorname{UMRK(t/ha)}$ & TRY(t/ha) \\
\hline NASPOT 13 & $72.91^{\mathrm{b}}$ & 134.00 & $21.33^{\mathrm{a}}$ & $591.67^{b}$ & $58.08^{\mathrm{a}}$ & $1.80^{\mathrm{b}}$ & $59.88^{\mathrm{a}}$ \\
\hline LOCAL & $90.42^{\mathrm{a}}$ & 152.33 & $16.00^{\mathrm{b}}$ & $535.33^{\mathrm{cb}}$ & $50.02^{\mathrm{bc}}$ & $1.76^{\mathrm{b}}$ & $51.78^{\mathrm{bc}}$ \\
\hline KABOLI & $76.04^{\mathrm{b}}$ & 142.33 & $18.33^{\mathrm{ab}}$ & $447.33^{\mathrm{d}}$ & $34.44^{\mathrm{d}}$ & $3.25^{\mathrm{a}}$ & $37.69^{d}$ \\
\hline KABODE & $78.12^{\mathrm{b}}$ & 136.66 & $18.00^{\mathrm{ab}}$ & $680.00^{\mathrm{a}}$ & $45.40^{\mathrm{c}}$ & $1.00^{\mathrm{c}}$ & $46.4^{\mathrm{c}}$ \\
\hline NASPOT 12 & $71.87^{\mathrm{b}}$ & 135.00 & $17.66^{\mathrm{b}}$ & $501.67^{\mathrm{cd}}$ & $55.01^{\mathrm{ab}}$ & $2.17^{\mathrm{b}}$ & $57.18^{\mathrm{ab}}$ \\
\hline Mean & 77.91 & 140.06 & 8.26 & 541.26 & 48.59 & 2.15 & 50.74 \\
\hline LSD (5\%) & 12.36 & ns & 3.63 & 60.82 & 6.06 & 0.72 & 5.62 \\
\hline CV $(\%)$ & 8.72 & 7.20 & 24.19 & 6.17 & 6.19 & 18.37 & 5.52 \\
\hline
\end{tabular}

Means in columns and rows followed by the same letter(s) are not significantly different at $5 \%$ level of significance. Where $\mathrm{SR}=$ survival rate, DM=date to maturity, NRPP=average root number per plot, ARW=average root weight $(\mathrm{g}), \mathrm{MRK}=$ marketable fresh weight per hectare $(\mathrm{t})$; $\mathrm{UMRK}=\mathrm{unmarketable}$ fresh weight per hectare $(\mathrm{t})$; TRY=total root yield $(\mathrm{t})$.

\section{Conclusions and Recommendation}

Root and tuber crops like sweet potatoes are the most important crops that need to be cultivated for food security in countries like Ethiopia where population is growing fast, because of the highest yield potential per unit area. Through adaptation trial sweet potato varietal recommendations were 
made for four targeted areas from the results of the first set of multi-location trials conducted in southern Oromia to address the needs of resource-poor farmers. The result of the current investigation showed that the Phenology, Growth and yield variables recorded highly significantly different result among the Orange Fleshed Sweet Potato varieties evaluated in the study area. The combined analysis of variance of total root yield ( $\mathrm{t} / \mathrm{ha}$ ) indicated that there was highly significant $(\mathrm{P}<0.05)$ difference among varieties, locations and variety by location interaction. The presence of significant variety by location interaction effect showed that some cultivars adapted to wider locations, whereas others to specific locations.

The highest mean value of root number per plot (21.33 and 36.66) was recorded from Naspot-13, Naspot-12 and Naspot13 variety at Dufa, Boke and Gobicha sites, respectively. However the lowest $(16.00,19.33$ and 16.00) mean value of root number was recorded from Local Variety at all locations. The highest average fresh root weight (670.33g and 444g) was recorded for Kabode and NASPOT-13 Variety at all locations. On the other hand, the lowest average fresh root weight (447.33, 437.33g and 296.33g) was recorded by Kaboli variety at all locations. From the genotypes, Naspot13 and Naspot-12 gave highest total root yield per unit area, followed by local material. In this study, On the other hand, Kaboli gave the lowest $\left(43.09,27.19\right.$ and $\left.37.69 \mathrm{t} \mathrm{ha}^{-1}\right)$ total root yield across locations. Based on this, genotype Naspot13 and Naspot-12 were shown more environmental interactions and they were more adapted in wider locations.

Generally from this study, Naspot-13 and Naspot-12 sweet potato varieties were more adaptable, disease tolerant and high yielder and should be promoted to farmers of the study areas for optimum production. Other agronomic packages and nutritional trials should be done further for better consumption of the crop.

\section{Conflict of Interests}

The authors declare that they have no competing interests.

\section{Acknowledgements}

I am very grateful to express my sincere gratitude to Oromia Agricultural Research Institute for granting fund for this study. I also want to extend my appreciation and special thanks to Bore Agricultural Research Center of Horticulture and spice research team for helping me in preparing the field layout of the experiment and for sharing me their practical knowledge in crop field management and for they provided me from the beginning to the end of the research work.

\section{References}

[1] Central Statistical Agency, 2014. Crop Production Forecast Sample Survey, 2013/14. Report on Area and Production for Major Crops (for Private Peasant Holdings 'Meher' season). Addis Ababa, Ethiopia.
[2] Dan. J., Mary. K. G., and Leigh A., (2013). Sweet Potato Value Chain: Ethiopia, EPAR (Evans School Policy Analysis and Research) Brief No 219, Wevans School of Public Affairs, University of Washigton.

[3] Egbe, O. M., S. O. Afuape and J. A. Idoko, 2012. Performance of improved sweet potato (Ipomea batatas L.) varieties in Makurdi, Southern Guinea Savanna of Nigeria. American Journal of Experimental Agriculture, 2: 573-586.

[4] Emanna Gutu. 1990. Integrated approach for the control of sweet potato weevil, cylclaspuncticollis Bob (Coleoptera: curclionidae). In: proceedings of the 10th annual meeting of crop protection society of Ethiopia.

[5] Endale T., Terefe B., Mukgeta D., and Geleta L. 1994. Improvement study on Enset and sweet potato. In: proceedings of second national horticultural workshop in Ethiopia. 1-3 December. 1992. Addis Ababa Ethiopia.

[6] Engida Tsegaye, Mihertu Cherinet, Asfaw Kifle, Daniel Mekonen and Tesfaye Tadesse, 2009. Genotype x Environment Interactions and Yield Stability of Orange Fleshed Sweet potato Varieties Grown in Ethiopia. Tropical Roots and Tubers in a Changing Climate. A Critical Opportunity for the World. 2-6 Nov 2009 Lima, Peru.

[7] Low, J., W. Thomas and H. Robert, 2001. The potential impact of orange fleshed sweet potato on vitamin A intake in subSaharan Africa. Proceedings of the Regional Workshop on Food Based Approaches to Human Nutrition Deficiencies, May 9-11, 2001, Nairobi, Kenya.

[8] Low, J. W., M. Arimond, N. Osman, B. Cunguara, F. Zano and D. Tschirley, 2007. A food-based approach introducing orange-fleshed sweet potatoes increased vitamin A intake and serum retinol concentrations in young children in rural Mozambique. J. Nutr., 137: 1320-1327.

[9] Maniyam Nedunchezhiyan, Gangadharan Byju, Susantha K Jata (2012) Sweet Potato Agronomy, Fruit, Vegetable and Cereal Science and Biotechnology. Global Science Books 1: $1-10$.

[10] Moussa, S. A. M., A. Hala, A. EI-Al and N. A. EI - Fadi. 2011. Stability study of sweet potato yield and its component characters under different Environments by Joint Regression Analysis., Journal of Horticultural Science and Ornamental plants. 3 (1) pp. 43 - 54. Sadat Branch, Egypt.

[11] Mulema JK, Adipala E, Olanya OM, Wagoire W (2008). Yield stability analysis of late blight resistant potato selections. Experimental Agriculture. 44: 145-155.

[12] Paneque R., 1991. Cultivation, Harvesting and Storage of Sweet Potato Products: Roots, Tubers, Plantations and Bananas in animal feeding.

[13] Purseglove, J. W., 1972. Tropical crops: Dicotyledons. London, longman.

[14] SAS., 2003. SAS Online Doc, Version 9.3. SAS Institute Inc., Cary NC., USA.

[15] Tesfaye T., Engida T., Aseffa T., Teshome A., Asfawu K., Yohannis G., Daniel M., 2011. Performance of medium and late maturing sweet potato germplasms in different agro ecologies of Ethiopia. In: Proceedings of the 14th annual conference of the crop science society of Ethiopia. 28-29 April 2011. Addis Ababa, Ethiopia. 
[16] Wariboko, C. and I. A. Ogidi, 2014. Evaluation of the performance of improved sweet potato (Ipomoea batatas L. LAM) varieties in Bayelsa State, Nigeria. Afr. J. Environ. Sci. Technol., 8: 48-53.

[17] Woolf, J. A., 1992. Sweet potato: An untapped food resource. Cambridge University, Great Britain.
[18] Yared D., Tewodros M. and Asfaw K., 2014. Development of High Yielding Taro (Colocacia esculenta L.) Variety for Mid Altitude Growing Areas of Southern Ethiopia. Journal of Plant Sciences. Vol. 2, No. 1, 2014, pp. 50-54. doi: 10.11648/j.jps.0201.19. 